\title{
The Influences of Chloride Anions on Corrosion Electrochemical Characteristics of 904L Stainless Steel in Blast Furnace Gas/Water system
}

\author{
Liang chao Chen ${ }^{1}$, Pei Zhang ${ }^{2}$, Qing yun Xiong ${ }^{3}$, Pan Zhao ${ }^{3}$, Jin ping Xiong, ${ }^{3, *}$, Yong Zhou ${ }^{4, * *}$ \\ ${ }^{1}$ College of Mechanical and Electrical Engineering, Beijing University of Chemical Technology, \\ Beijing 100029, China \\ ${ }^{2}$ Guangxi Key Laboratory of Agricultural Resources Chemistry and Biotechnology, College of \\ Chemistry and Food Science, Yulin Normal University, Yulin 537000, China \\ ${ }^{3}$ College of Materials Science and Engineering, Beijing University of Chemical Technology, Beijing \\ 100029, China \\ ${ }^{4}$ Key Laboratory for Green Chemical Process of Ministry of Education, Wuhan Institute of \\ Technology, Wuhan 430205, China \\ *E-mail: xiongjp@mail.buct.edu.cn \\ ** E-mail: zhouyong@wit.edu.cn
}

doi: $10.20964 / 2019.01 .78$

Received: 2 October 2018 / Accepted: 13 November 2018 / Published: 30 November 2018

In this work, the influences of chloride anion $\left(\mathrm{Cl}^{-}\right)$concentrations on the corrosion electrochemical characteristics for a super austenitic stainless steel (ASS), 904L ASS, in a simulated environmental solution that was acquired with the introduction of blast furnace gas (BFG) into water were investigated with the methods of electrochemical techniques including potentiodynamic polarization, electrochemical impedance spectroscopy (EIS), current transient and Mott-Schottky plot. From the electrochemical measurement and investigation, the results showed that 904L ASS presented the electrochemical behavior of self-passivation in the BFG/water solutions with different concentrations of $\mathrm{Cl}^{-}$, and the influences of $\mathrm{Cl}^{-}$concentrations on the main corrosion electrochemical parameters, including pitting potential $\left(E_{p i t}\right)$, passivation current density $\left(i_{\text {pass }}\right)$, repassivation potential $\left(E_{\text {rep }}\right)$, passive film capacitance $\left(C E P_{f}\right)$, passive film resistance $\left(R_{f}\right)$, flat bond potential $\left(U_{f b}\right)$ and donor density $\left(N_{D}\right)$, were very prominent and showed a certain rule. Further, the 904L steel presented the good self-passivation characteristic in the BFG/water solution when the $\mathrm{Cl}^{-}$concentration was lower than $78.50 \mathrm{~g} / \mathrm{L}$. However, when the $\mathrm{Cl}^{-}$concentration was higher than $78.50 \mathrm{~g} / \mathrm{L}$, the self-passivation characteristic of 904L ASS decreased gradually with the increase of $\mathrm{Cl}^{-}$concentration. Further, the relation between corrosion and passivation characteristics was also discussed in this paper. 
Key words: 904L ASS; corrosion and passivation; blast furnace gas; chloride anion; polarization; EIS; Mott-Schottky

\section{FULL TEXT}

(C) 2019 The Authors. Published by ESG (www.electrochemsci.org). This article is an open access article distributed under the terms and conditions of the Creative Commons Attribution license (http://creativecommons.org/licenses/by/4.0/). 